\title{
Strategic surgical-combined orthodontic treatment planning of patient with missing incisors on maxilla: a case report
}

\author{
Je-Hyeok Park', Jin Jeon', Sen Zhao', Young-Mi Jeon ${ }^{1,2}$, Jong Ghee Kim, ${ }^{1,2 *}$ \\ 'Department of Orthodontics, Institute of Oral Biosciences and School of Dentistry, Chonbuk National University, Jeonju, \\ Republic of Korea \\ ${ }^{2}$ Research Institute of Clinical Medicine of Chonbuk National University-Biomedical Research Institute of Chonbuk National \\ University Hospital, Jeonju, Republic of Korea
}

Proper positioning of maxillary incisors is key to success of surgery combined treatment. Establishing surgery plan would be a difficult job if maxillary incisors are lost. Patient who lost all of her maxillary incisors due to accident came for orthodontic treatment. Through careful modification of maxillary archform, pre-surgical orthodontic treatment was conducted with four prosthetic space consolidation. Position of incisors was decided by help of 3D prosthetic set-up, and 1-jaw surgery was planned. After relative short treatment period of 28 months, final prosthesis was done. When alveolar bone loss happens, harmonious prosthesis of upper incisors is difficult. Utilizing mandibular set-back surgery and incisor positioning using 3D set-up could make a better environment for treatment outcome. Strategic pre-surgical orthodontic treatment can allow shorter time and less number of prosthetics. (J Dent Rehabil Appl Sci 2019;35(4):244-52)

Key words: incisor teeth loss; orthognathic surgery; pre-surgical orthodontic treatment

\section{서론}

골격성 부정교합의 치료법은 크게 비수술 절충치료와 악교정수술을 동반한 교정치료로 나뉜다. ${ }^{1,2}$ 골격성 고정 원의 도입으로 교정적 치아이동의 범위가 확장되어 교정 적 절충치료와 수술을 동반한 교정치료의 경계선상의 증 례(borderline cases)가 증가하였다. ${ }^{3}$ 하지만 절충치료로 수술을 대체 가능한 몇 가지 부정교합 증례를 제외하고 는 여전히 하악 전돌을 보이는 III급 부정교합의 치료는 심미적 고려사항 등 여러 요인을 감안하여 치료 방향의 결정이 필요하다. ${ }^{4}$

골격성 III급 부정교합 환자가 외상으로 인해 상악 전 치부가 결손된 경우, 수술 혹은 비수술 치료 방향의 결정

*Correspondence to: Jong Ghee Kim

Professor, Department of Orthodontics, School of Dentistry, Chonbuk National University, 20, Geonji-ro, Deokjin-gu, Jeonju, 54907, Republic of Korea Tel: +82-63-250-2123, Fax: +82-63-250-2139, E-mail: kjgortho@jbnu.ac.kr Received: September 17, 2019/Last Revision: October 24, 2019/Accepted: November 11,2019
이 매우 어렵다. 절충치료를 선택할 경우 치아 결손으로 인한 순측 치조골의 흡수로 인해 조화롭고 심미적인 보 철 수복이 어려우며, 상악 전치의 순측경사로 인해 치료 의 결과가 종종 만족스럽지 못하다. ${ }^{5}$ 수술을 동반한 교정 치료를 선택하는 것 역시 쉽지 않은 선택인데, 악교정 수 술 시 성공의 가장 큰 열쇠는 상악 전치의 위치 결정이며 상악 전치가 전부 결손된 경우 정확한 수술계획의 수립 이 어렵다. 본 증례 보고는 외상으로 인해 상악 전치를 모 두 상실하여 보철 수복을 위해 의뢰된 환자로, 상기한 여 러 어려움에도 불구하고 수술을 동반한 전략적 교정치료 를 시행하여 조화로운 교합 회복을 달성하여 이를 보고 하고자 한다.

Copyright(C) 2019 The Korean Academy of Stomatognathic Function and Occlusion. (c) It is identical to Creative Commons Non-Commercial License. 


\section{증례보고}

\section{Diagnosis}

19세 여환이 하악 전돌로 인해 전치부 보철치료를 하 기에 적합하지 않다는 주소로 OO대학병원 보철과에서 의뢰되었다. 환자는 2년 전 교통사고로 인해 6전치가 탈 구 및 파절되어 OO대학교병원 구강외과 및 보존과에서 치료받은 병력이 있었다(Fig. 1). 안모 사진 상에서 하악 전돌감 및 concave한 profile을 보였으며, 심미선에 대한 상순의 후퇴를 보였다. 구강 내 소견 상 12번부터 23번 까지의 치아 missing, 정중선 비대칭, 전치부 반대교합 및 하악 전치부 crowding을 보였으며, 구치부 교합은 약간 의 III급 관계를 보였으나 그 정도가 심하지 않았다(Fig. 2). 측모두부방사선 사진 분석상에서 hypodivergent한 pattern의 골격적 III급 증례임을 확인 가능하였다(Table 1). 정면 두부방사선사진상 상악골의 약간의 canting 보 이나 제 1대구치 상에서는 거의 canting이 존재하지 않았 다(Fig. 3). 상기 진단 자료를 분석하여 다수 치아의 상실 을 동반한 hypodivergent 골격성 III급 증례로 진단하였 다.

\section{Treatment plan}

골격성 III급 부정교합 치료는 크게 교정적 절충치료 및 악교정수술을 동반한 수술교정 치료로 나뉜다. 교정적 절충치료의 경우 6전치의 임플란트 수복이 필수적이었으 며, 환자는 성장기 종료 시점을 기다리던 중 상당량의 치 조골이 소실되었으며 6전치 임플란트 수복이 보철적으 로 불가능하다는 평가로 의뢰되었다. 또한 환자는 하악

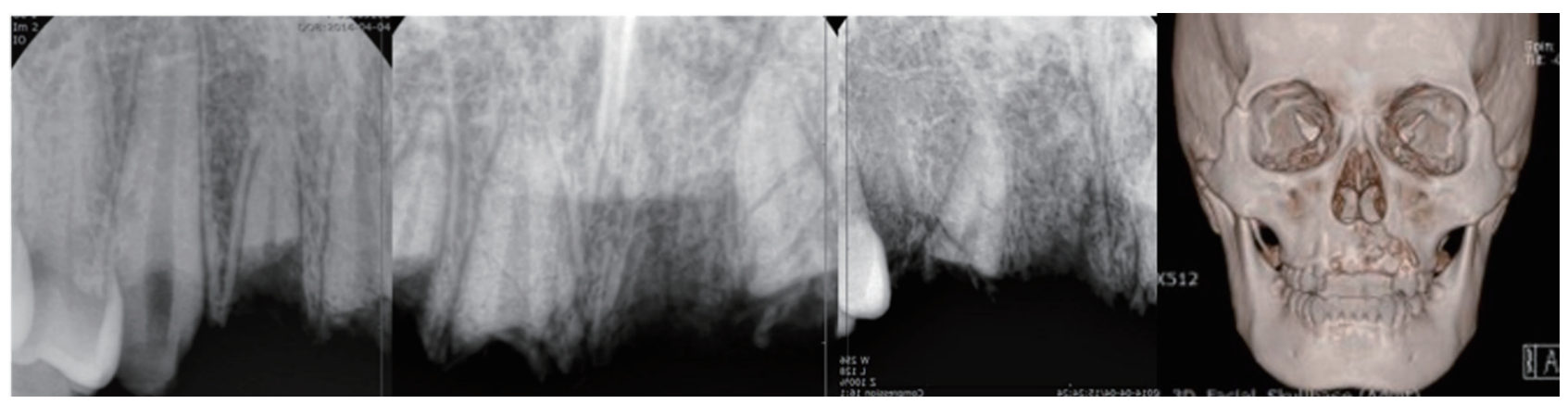

Fig. 1. Radiographs of patient obtained at the time of trauma.

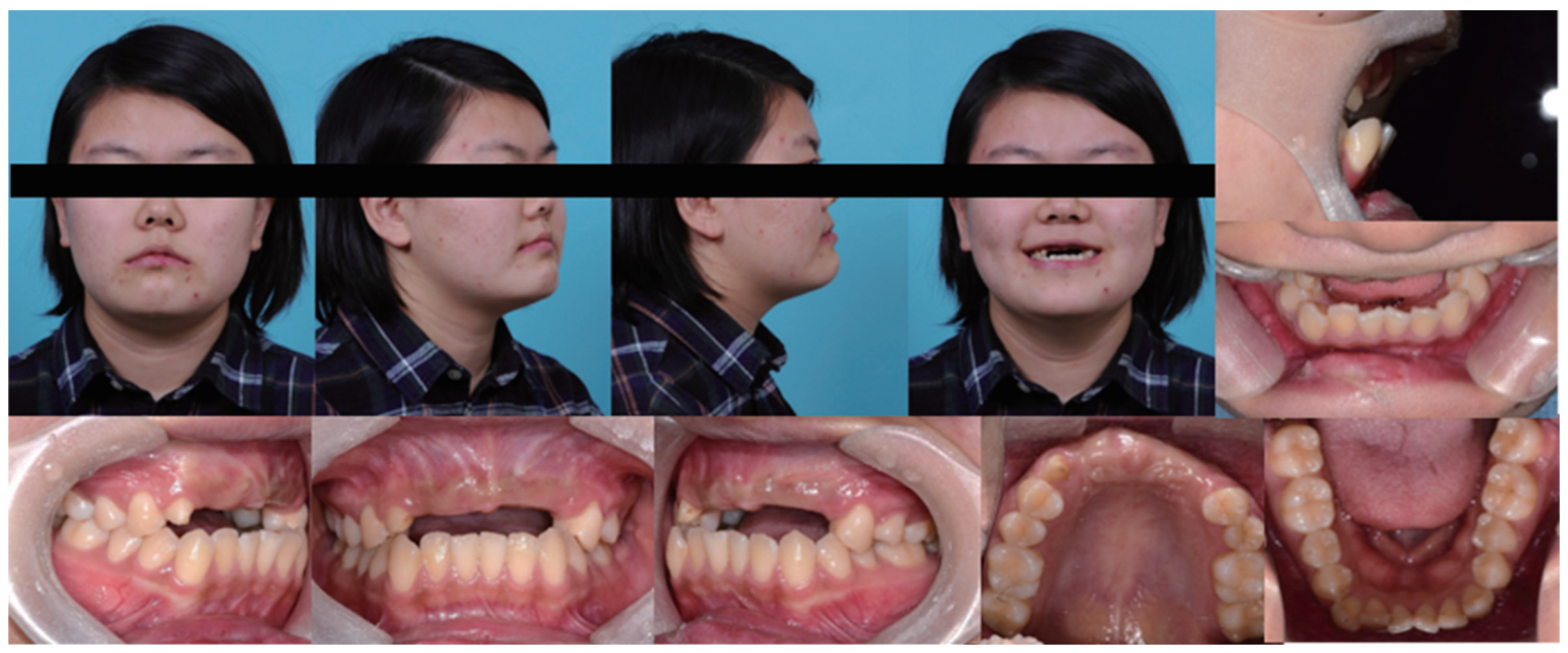

Fig. 2. Extraoral and intraoral photos of patient obtained before orthodontic treatment. 


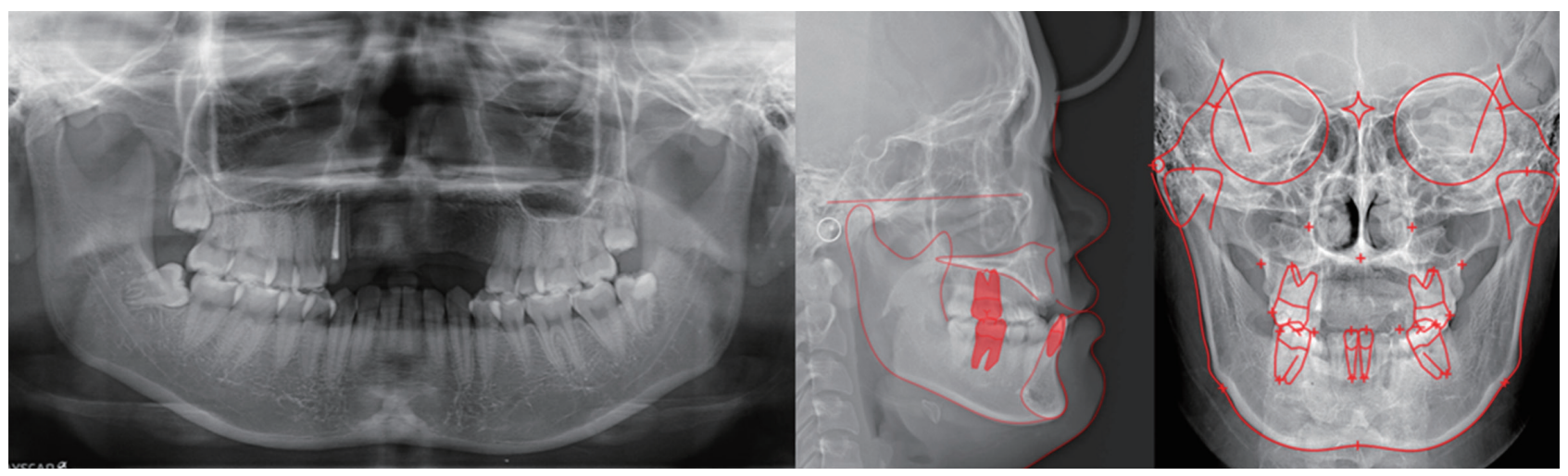

Fig. 3. Cephalometric and panoramic x-rays obtained before orthodontic treatment.
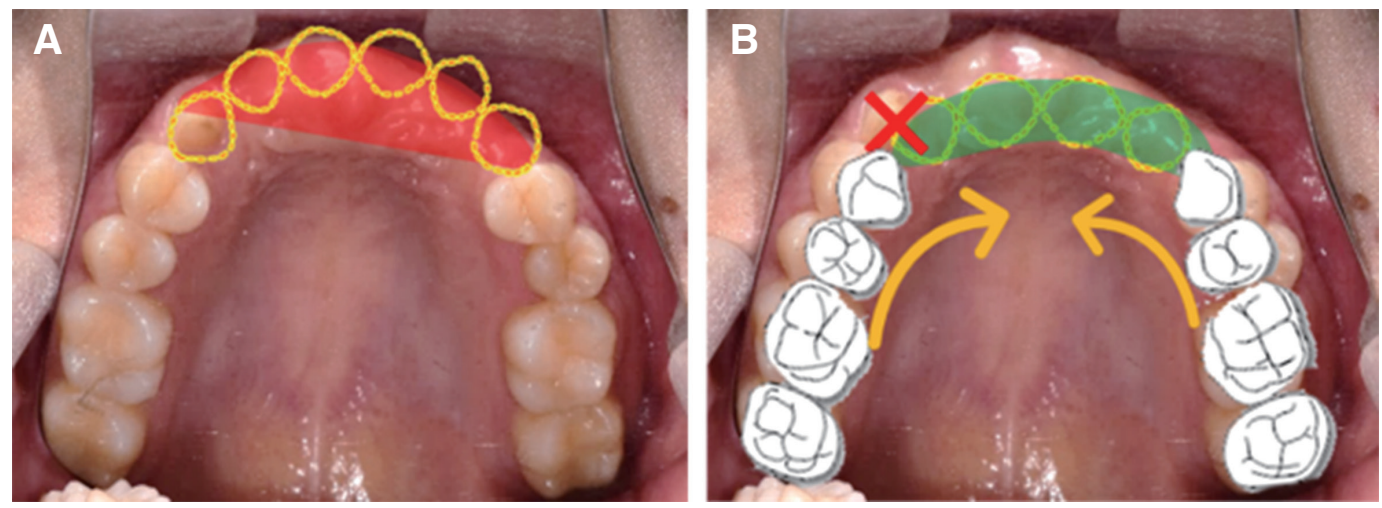

Fig. 4. Pre-surgical orthodontic treatment plan. (A) camouflage treatment with 6 prosthetics, (B) 4 prosthetics with modification of maxillary dentition.

돌출감의 개선을 원하였으며, 따라서 교정적 절충치료는 적합한 치료계획이 될 수 없었다(Fig. 4A).

이에 악교정수술을 동반한 수술교정치료를 계획하였 다. 상악 전치부 임플란트 식립 시 최대한 잔존 치조골이 풍부한 부위를 사용할 수 있도록 대합치를 후방이동시키 기 위해 하악골 set-back surgery를 계획하고, 동시에 환 자에게 최소한의 보철치료를 시행할 수 있도록 전략적인 술전교정을 시행하기로 하였다. 치은연하 파절로 인해 장기적인 예후가 의심스러운 \#13을 발치하고, \#14,24 를 견치화 함과 동시에 전반적으로 상악궁의 형태 조절 을 계획하였다. 형태가 조절된 상악궁 전방부에 4 개의 전 치 보철 공간을 형성하여 마치 상악 소구치 편악발거를 시행한 것과 같은 술전교정 효과를 노리고자 하였다(Fig. 4B). 이후 악교정수술과 동시에 상악골 임플란트를 식립 하고, 술후 마무리 교정 및 보철수복을 시행하기로 치료 계획을 수립하였다.

\section{Treatment progress}

치료 4개월차 precision lingual arch를 engage하여 상 악궁의 형태 조정을 시작하였으며, 환자의 심미적 요구 로 임시치아를 결찰하였다(Fig. $5 \mathrm{~A}$ ). 치료 시작 9개월차 하악 wire를 상악에 engage하고, \#14-24 사이에 powerchain을 결찰하며 정중구개봉합 부위에 골격성 고정원을 식립하여 상악궁의 형태 조정을 더욱 활성화하였다(Fig. $5 \mathrm{~B})$. 치료 시작 12 개월 차로, 술전교정이 종료되었다(Fig. 5C). 초진과 술전교정 종료 후의 cast superimposition 상 6 개의 치아 결손 부위를 악궁의 형태변형을 통해 4 개의 임플란트 공간을 형성하였으며, 동시에 하악에서는 치아 배열 및 decompensation이 이루어졌다. 이후 술전진단을 위한 자료를 채득하여 model surgery를 계획하였다(Fig. 6).

구강외과의와의 상의 끝에 환자의 치료기간을 최소 

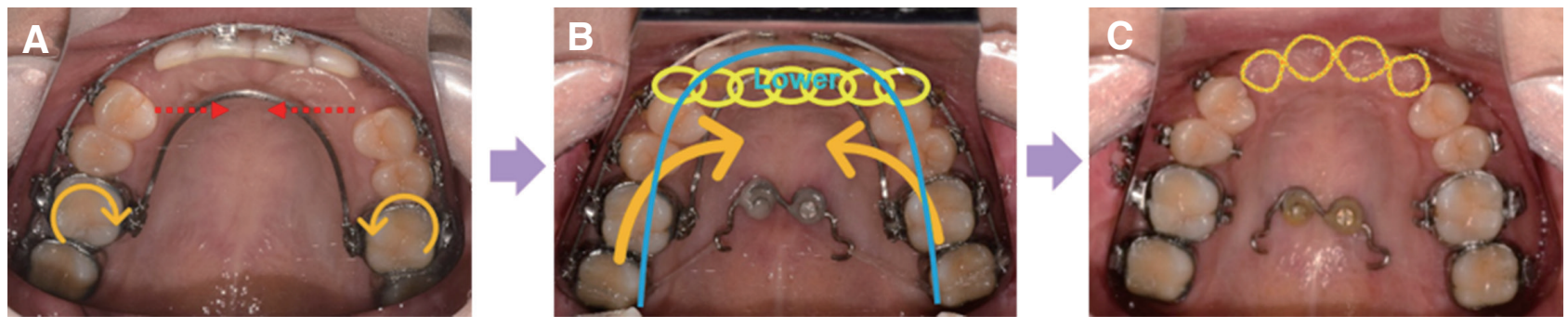

Fig. 5. Pre-surgical orthodontic treatment progress. (A) Photographic image at 4 months, (B) Photographic image at 9 months, (C) Photographic image at 12 months.

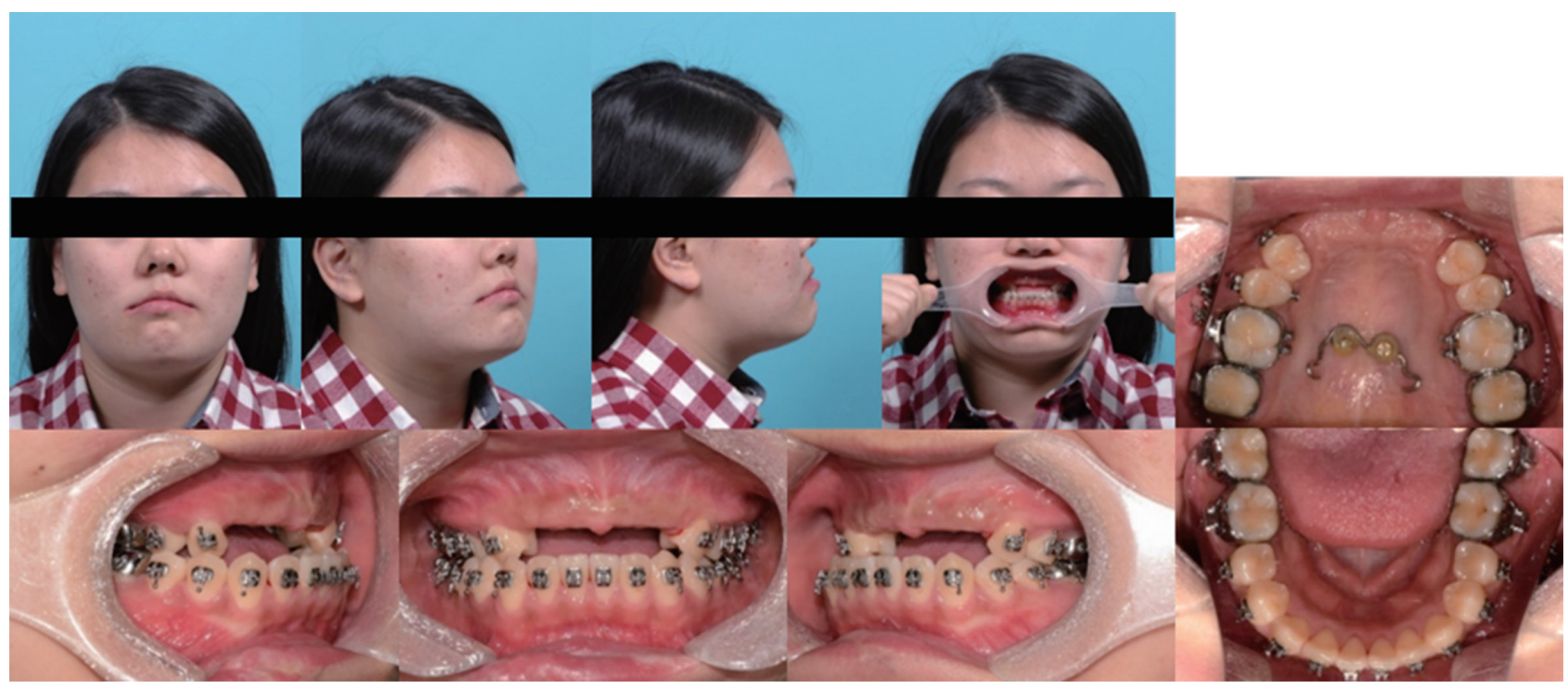

Fig. 6. Extraoral and intraoral photos of patient obtained after 12 months of treatment (pre-surgical assessment).

화하기 위해 악교정수술 시 동시에 상악 전치부의 bone graft 및 임플란트 식립을 시행하기로 하였으며, 따라서 수술 범위를 최소화하고 창상치유에 유리하도록 하악골 편악 수술이 계획되었다. 상악 전치가 모두 상실된 본 환 자의 특성 상 model surgery를 시행하기에 앞서 술 후 교 합을 결정하여야 하였고, 이를 위해 가상 치아수복 프로 그램(3shape Dental-system, Copenhagen, Denmark)을 사용하였다. 프로그램 상에서 상악 전치를 가상 수복하 여 최종 교합 상의 상악 전치의 위치 및 overjet/overbite 를 설정하고(Fig. 7A), 가상 치아수복 모델을 참고하여 수술계획을 수립하였으며(Fig. $7 \mathrm{~B}$ ), 계획된 교합을 교합 기로 옮겨 final wafer를 제작하였다(Fig. 7C).

계획된 술후교합에 맞추어 하악골 시상절단술을 통한
후방이동이 시행되었으며, 하악골을 plate와 screw를 사 용하여 강성고정한 후 wafer를 제거하여 condyle sagging 유무를 확인하였다. 후방이동된 하악전치와 조화로운 보 철을 시행할 수 있도록 상악 전치 골 결손부의 allogenic bone graft과 함께 4전치 임플란트를 식립하였다.

술후 4주간의 스플린트 착용 및 악간고정을 시행하였 으며(Fig. 8A), 치료 20개월 차 소구치부 box elastic과 함 께 최종교합을 형성하였다(Fig. 8B). 치료 25개월 차 교정 장치를 제거하였으며 임시보철을 시행(Fig. 8C), 치료 28 개월 차 최종보철을 시행하였다. 환자는 비교적 짧은 교 정기간 내에 바람직한 기능교합과 자신감 있는 미소를 되찾을 수 있었다(Fig. 9, 10, Table 1). 

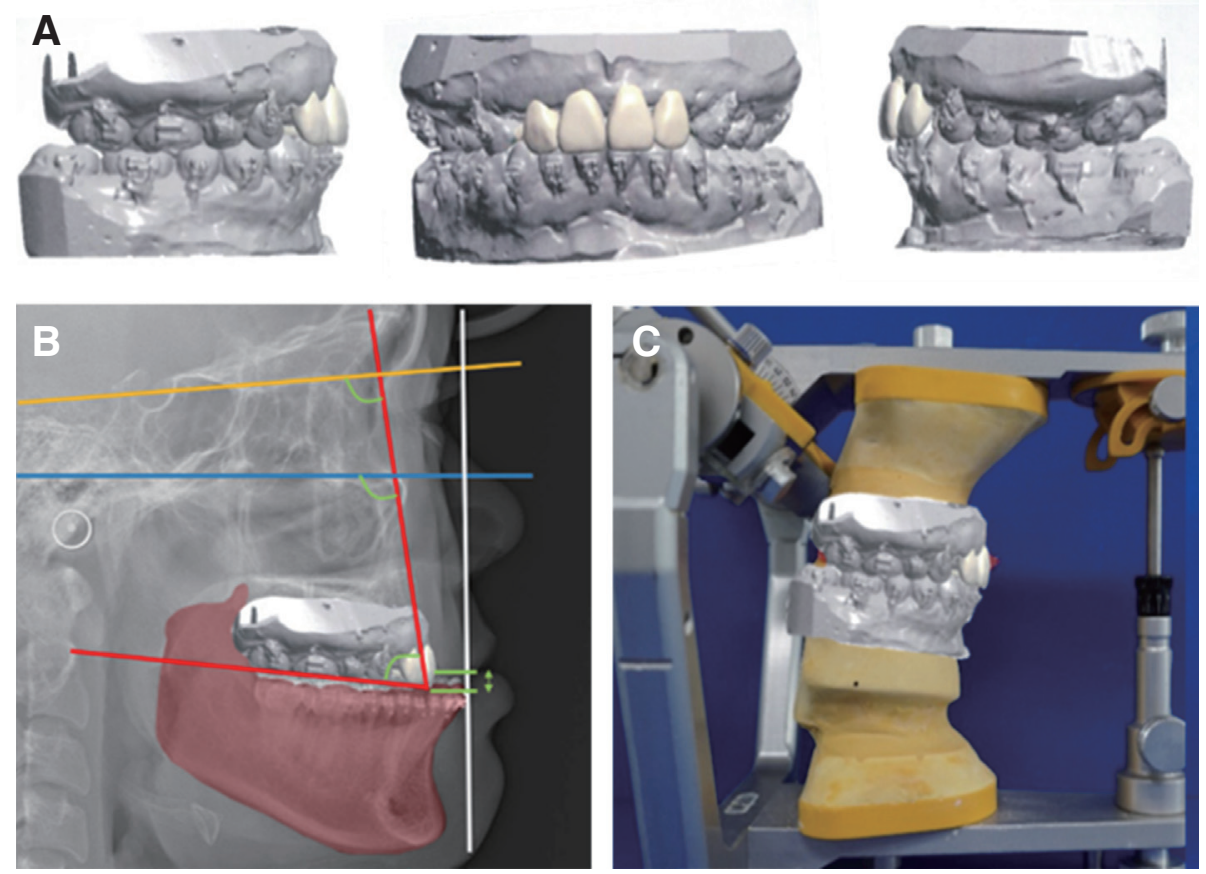

Fig. 7. Model surgery progress. (A) Incisor positioning with 3D program, (B) Paper surgery with positioned incisors, (C) Final occlusion for surgical wafer.
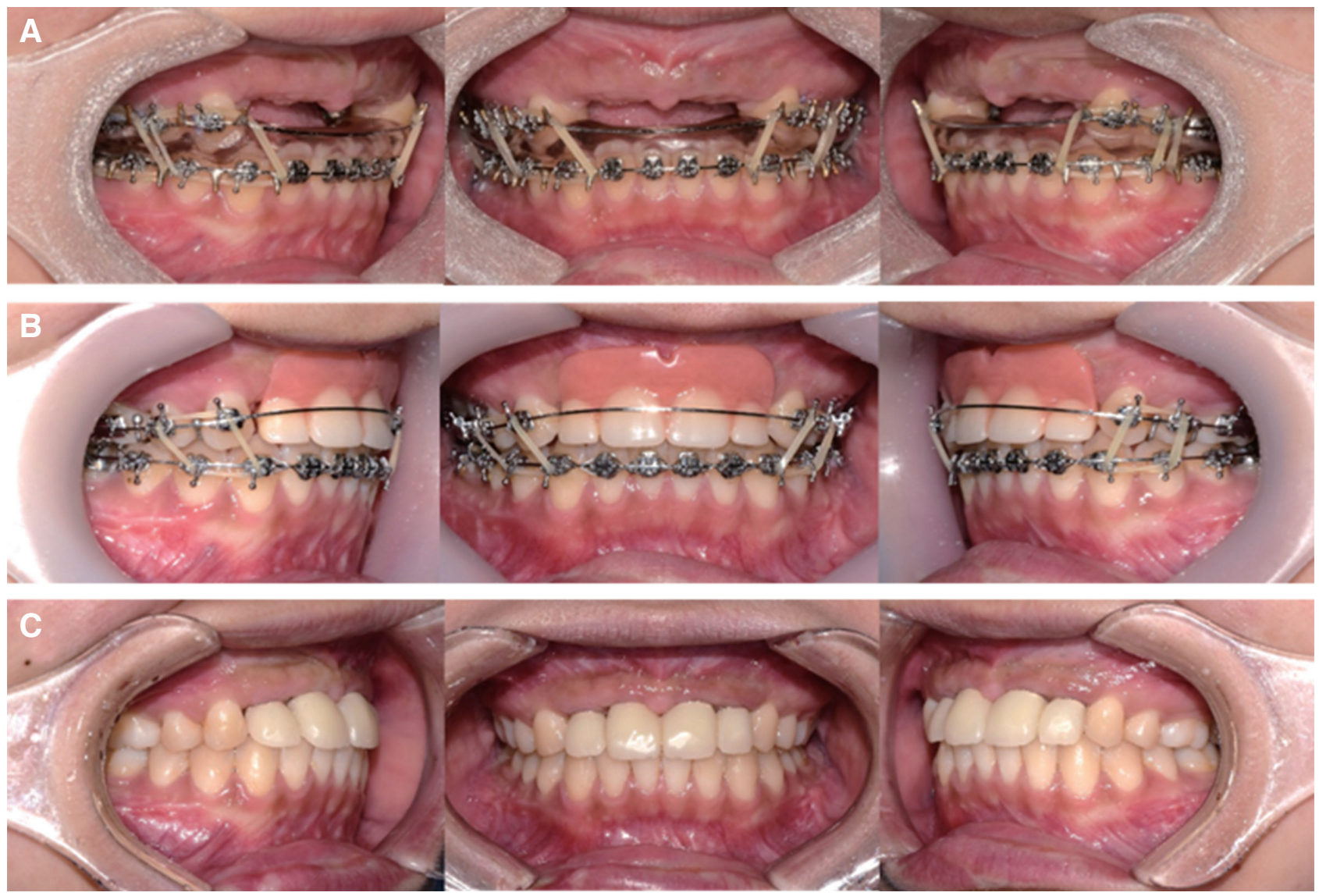

Fig. 8. Post-surgical orthodontic treatment progress. (A) 4 weeks after surgery, (B) 7 months after surgery, (C) Appliance removal with provisional restoration. 


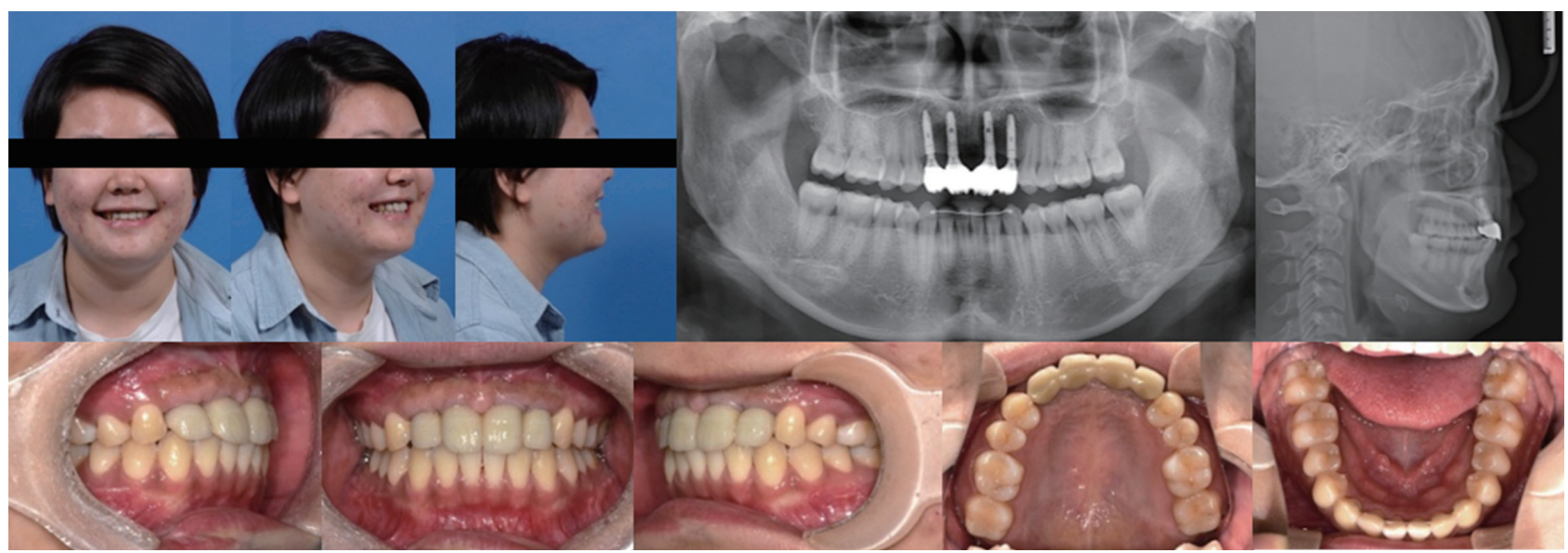

Fig. 9. Extraoral and intraoral photos, radiograph data obtained after final prosthesis.

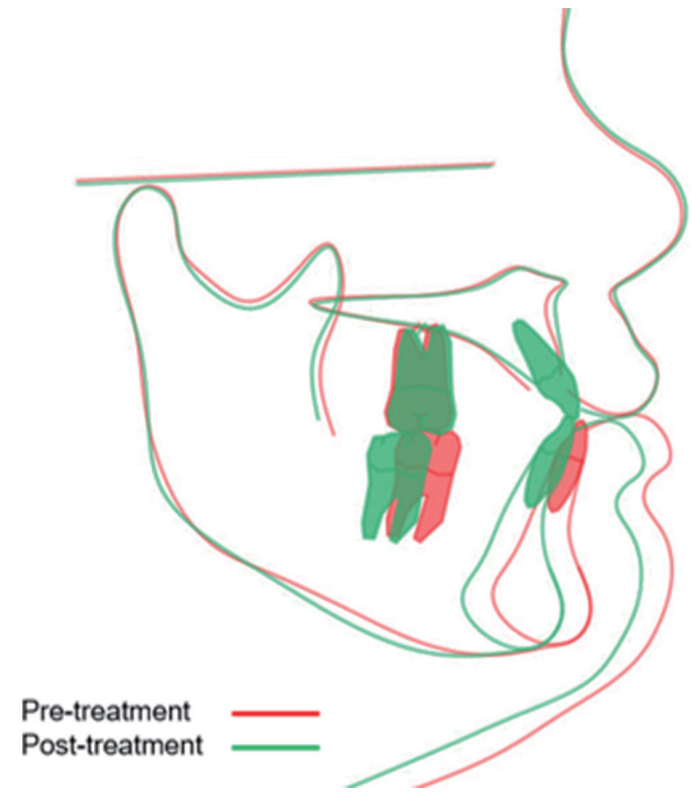

Fig. 10. Superimposition of pre-treatment and treatment result. Red line: pre-treatment, Green line: post-treatment.

\section{고찰}

대부분의 III급 부정교합 수술 증례는 매우 심한 구치 부 근심교합을 보이나, ${ }^{1,2}$ 본 증례는 거의 I급에 가까운 구 치부 관계를 보였음에도 불구하고 전치 수복이 불가능할
Table. 1. Cephalometric measurements obtained during orthodontic treatment

\begin{tabular}{lrrcc}
\hline & Mean & S.D. & $\begin{array}{c}\text { Pre- } \\
\text { treatment }\end{array}$ & $\begin{array}{c}\text { Post- } \\
\text { treatment }\end{array}$ \\
\hline SNA & 81.6 & 3.2 & $86.6^{*}$ & $87.3^{*}$ \\
SNB & 79.2 & 3.0 & $87.3^{* *}$ & 83.5 \\
ANB & 2.5 & 1.8 & $-0.7^{*}$ & 3.8 \\
FMA & 24.3 & 4.6 & $18.2^{* *}$ & 21.3 \\
FHR & 66.8 & 4.3 & $75.5^{* * *}$ & $72.3^{*}$ \\
U1 to SN & 106.9 & 6.0 & - & 113.3 \\
U1 to FH & 116.0 & 5.8 & - & 119.4 \\
IMPA & 95.9 & 6.4 & 93.0 & 96.3 \\
IIA & 123.8 & 8.3 & - & 123.0 \\
UL/E-L & -0.9 & 2.2 & $-4.0^{*}$ & -2.2 \\
LL/E-L & 0.6 & 2.3 & -1.0 & -2.4 \\
\hline
\end{tabular}

$*, * *, * * *$ indicates the value is beyond one, two, or three times of the standard deviation. SNA, the angle of sella-nasion-A point; SNB, the angle of sella-nasion-B point; ANB, the angle of A point-nasionB point; FMA, Frankfort mandibular plane angle; FHR, Facial height ratio; $\mathrm{U} 1$ to $\mathrm{SN}$, the angle of the long axis of maxillary central incisors between sella-nasion plane; $\mathrm{U} 1$ to $\mathrm{FH}$, the angle of the long axis of maxillary central incisors between Frankfort plane; IMPA, the angle of the lowermost tangent to the mandible and the long axis of mandibular incisors; IIA, interincisal angle; UL/E-L, distance between esthetic line and upper lip; LL/E-L, distance between esthetic line and lower lip.

정도의 심한 anterior crossbite 및 골격성 III급 관계를 보 여 수술이 불가피하였다. 이 원인에 대해 고찰하기 위해 사고 당시의 측모두부방사선 사진과 이로부터 2년여 지 난 교정과 내원 시의 측모두부방사선사진을 중첩해 보았 다(Fig. 10). 사고 당시에 비해 설측 방향으로의 골 흡수 


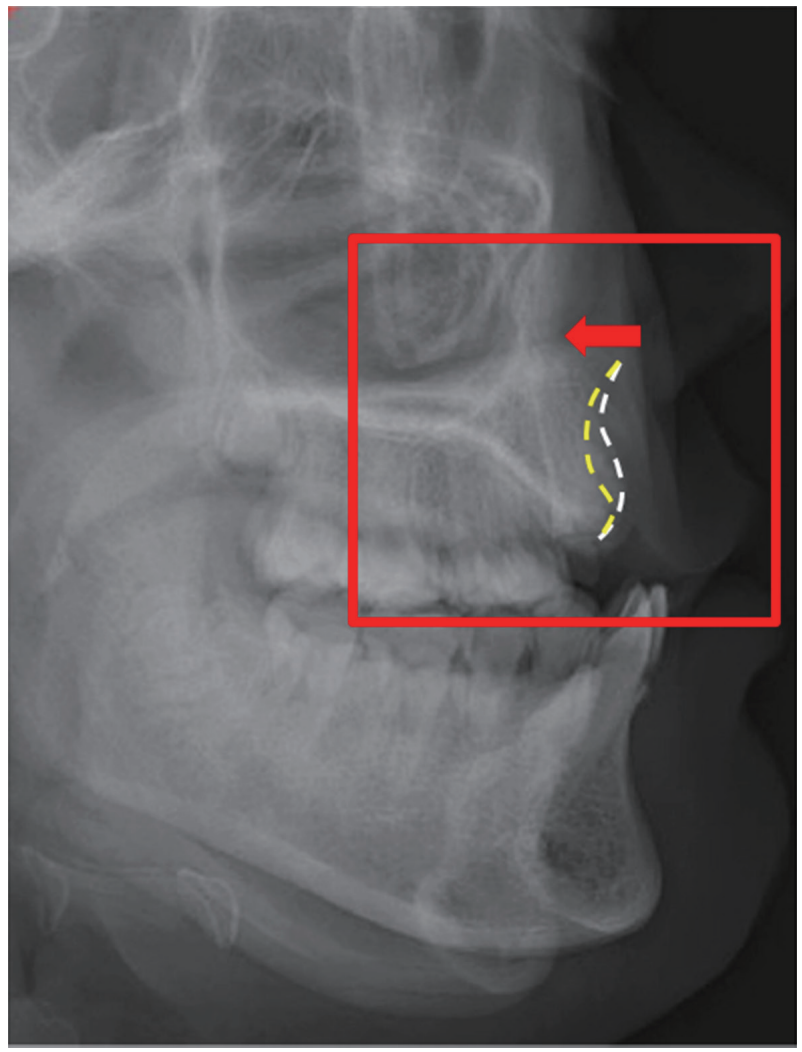

Fig. 11. X-ray superimposition. White line: at-trauma, Yellow line: after 2-years. Resorption of maxillary alveolar bone (Red box) is prominent (Red arrow).

가 진행된 것이 관찰되며, 따라서 환자의 골격성 III급 부 정교합이 전치부 상실 이후의 치조골 흡수로 인해 더 악 화되었다는 것을 알 수 있었다. 치아상실은 심미적 및 기 능적 손상을 가져오며, 이에 수반되는 치조골의 위축 역 시 큰 문제가 된다. ${ }^{6}$ Atwood 등은 치아 상실 후 대부분 의 골 상실은 발치 후 1 년 내에 일어나며, 전치 및 견치 부 위에서 구치부보다 더 크게 골이 흡수됨을 보고하였다. ${ }^{7}$ 따라서 외상 후 골이 상실되기 전에 가능한 한 빨리 보철 을 시행하는 것이 이상적이나, 본 환자의 경우 외상 당시 잔여성장이 남아 있는 나이로 성장 완료시까지 관찰이 필요하였다. 이러한 경우 외상 부위의 치근을 발치하지 않고 전략적으로 남겨두는 방법이 추후 보철수복을 위 해 유리하며, ${ }^{8}$ 본 증례에서도 외상 후 보존이 가능하였던 \#11,12,13 치근 부위의 골이 그렇지 못하였던 \#21-23 부 위의 치조골에 비해 덜 위축되었음을 관찰할 수 있었다.

외상으로 상악 전치가 모두 결손된 환자에서 정확한 수술계획을 수립하는 일은 매우 어렵다. Wolford 등은
악교정 수술을 계획 시 참고할 두부계측치 중 가장 중요 한 세가지는 상악 전치의 수직적 위치, 전후방적 위치, 교 합평면의 경사라고 주장하였다. ${ }^{9}$ 수술 시 상악 전치의 3 차원적인 위치는 수술 시 상악골에 대한 하악골의 상대 적 위치를 결정하게 되므로 치료계획에 필수적인 요소이 다. 본 증례는 하악골 편악수술로 진행되어 전치부의 전 후방적인 위치 및 술 후 overjet을 확인하기 위해 간단한 $3 \mathrm{D}$ 가상보철 만으로도 만족스러운 결과를 얻을 수 있었 으나, 상악골 수술을 함께 계획해야 할 증례일 경우 수술 계획 시 최근 발전하고 있는 3 차원 가상수술법을 활용한 다면 좀더 정밀하게 상악 전치의 위치를 결정할 수 있을 것으로 생각된다. ${ }^{10,11}$

\section{결론}

골격성 피급 부정교합 환자가 외상으로 인해 상악 전 치를 모두 소실한 경우, 교정적 절충치료의 결과가 좋지 못하여 악교정수술이 필요할 수 있으나 이를 계획하는 것 역시 쉽지 않다. 본 증례는 이를 극복하기 위해 $3 \mathrm{D}$ 가 상 치아수복을 활용하였으며, 전략적인 술전교정을 통해 보철수복 수를 최소화하였다. 또한 하악골 편악수술 및 임플란트 식립의 동시 진행으로 비교적 짧은 교정치료로 바람직한 기능교합을 획득할 수 있었다.

\section{ORCID}

Je-Hyeok Park https://orcid.org/0000-0002-1726-9933

Jin Jeon https://orcid.org/0000-0001-6564-7348

Sen Zhao https://orcid.org/0000-0002-9208-5026

Young-Mi Jeon https://orcid.org/0000-0003-1446-313X

Jong Ghee Kim https://orcid.org/0000-0002-6138-0006

\section{References}

1. Proffit WR, Fields Jr HW, Sarver DM. Contemporary Orthodontics. 5th ed. Elsevier; 2012. p. 693-9.

2. Graber T, Vanarsdall R, Vig K. Orthodontics, current principles and technique. 6th ed. Elsevier; 2017. p. 784-91.

3. Ngan P, Moon W. Evolution of Class III treatment in orthodontics. Am J Orthod Dentofacial Orthop 2015;148:22-36.

4. Nicodemo D, Pereira MD, Ferreira LM. Effect of 
orthognathic surgery for class III correction on quality of life as measured by SF-36. Int J Oral Maxillofac Surg 2008;37:131-4.

5. Lin J, Gu Y. Preliminary investigation of nonsurgical treatment of severe skeletal Class III malocclusion in the permanent dentition. Angle Orthod 2003;73:401-10.

6. Atwood DA. Postextraction changes in the adult mandible as illustrated by microradiographs of midsagittal sections and serial cephalometric roentgenograms. J Prosthet Dent 1963;13:810-24.

7. Atwood DA. Bone loss of edentulous alveolar ridges. J Periodontol 1979;50:11-21.

8. Cohenca N, Stabholz A. Decoronation - a conservative method to treat ankylosed teeth for preservation of alveolar ridge prior to permanent prosthetic reconstruction: literature review and case presentation. Dent Traumatol 2007;23:87-94.

9. Wolford LM, Chemello PD, Hilliard FW, Occlusal plane alteration in orthognathic surgery. J Oral Maxillofac Surg 1993;51:730-40.

10. Aboul-Hosn Centenero $S$, Hernández-Alfaro F. $3 \mathrm{D}$ planning in orthognathic surgery: $\mathrm{CAD} / \mathrm{CAM}$ surgical splints and prediction of the soft and hard tissues results - our experience in 16 cases J Craniomaxillofac Surg 2012;40:162-8.

11. Hammoudeh JA, Howell LK, Boutros S, Scott MA, Urata MM. Current status of surgical planning for orthognathic surgery: traditional methods versus 3D surgical planning. Plast Reconstr Surg Glob Open 2015;3:e307. 


\section{상악 전치부 결손 환자의 수술을 동반한 전략적 교정치료 증례}

\section{박제혁', 전진 ${ }^{1}$, Zhao Sen ${ }^{1}$, 전영미 ${ }^{1,2}$, 김정기 ${ }^{1,2 *}$}

${ }^{1}$ 전북대학교 치의학전문대학원 치과교정학교실

${ }^{2}$ 전북대학교병원 임상연구지원센터

상악 전치의 위치 결정은 수술을 동반한 교정치료의 성공을 위해 꼭 필요한 열쇠이다. 따라서 상악 전치가 전부 소실된 환자에서 수술계획을 수립하는 것은 매우 어려운 일이다. 본 환자는 상악 전치를 외상으로 인해 모두 상실하였으며, 보철 치료를 위한 교정치료를 주소로 내원하였다. 보철 개수를 최소화할 수 있도록 상악의 악궁 형태를 변형하여 4 개의 보철 공간을 확립하여 술전교정을 진행하였으며, $3 \mathrm{D}$ 가상 보철수복을 참고하여 상악 전치의 위치를 결정하고 하악골 편악수 술을 시행하였다. 악교정수술 시 상악골 이식술 및 임플란트 식립이 함께 진행되었으며 비교적 짧은 28개월의 교정치료 기간 후 치료를 마무리하였다. 골격성 III급 환자가 전치 소실 후 치조골이 함께 흡수된 경우 하악궁과의 조화로운 보철 수복이 매우 어려우며, 이와 같은 경우에 전략적인 술전교정을 통해 하악골 후방이동수술을 시행하는 것이 더 나은 치료 환경을 제공할 수 있을 것이다.

(구강회복응용과학지 2019;35(4):244-52)

주요어: 전치부 결손; 악교정 수술; 술전교정치료

*교신저자: 김정기

(54907) 전북 전주시 덕진구 건지로 20 전북대학교 치의학전문대학원 치과교정학교실

Tel: 063-250-2123 | Fax: 063-250-2139 | E-mail: kjgortho@jbnu. ac. kr

접수일: 2019년 9월 17일 | 수정일: 2019년 10월 24일 | 채택일: 2019년 11월 11일 